\title{
Threatened fishes of the world: Horabagrus nigricollaris (Pethiyagoda and Kottelat, 1994) (Bagridae)
}

\author{
G. Prasad • P. H. Anvar Ali • R. Raghavan
}

Published online: 5 July 2007

(C) Springer Science + Business Media B.V. 2007

\section{Erratum to: Environ Biol Fish DOI 10.1007/s10641-007-9259-9}

This erratum is being published as a result of Author's name was misspelt.

R. Rahgavan should be read as R. Raghavan

The online version of the original article can be found at http:// dx.doi.org/10.1007/s10641-007-9259-9.

G. Prasad $(\bowtie) \cdot$ P. H. Anvar Ali $\cdot$ R. Raghavan Department of Zoology, University of Kerala, Kariavattom, Trivandrum, Kerala 695 581, India e-mail: probios1@hotmail.com 